\title{
CORRELATIVE SCANNING AND TRANSMISSION ELECTRON MICROSCOPIC STUDY ON THE EPENDYMAL SURFACE OF BRADYPUS TRIDACTYLUS
}

\author{
CLAUDIO A. FERRAZ DE CARVALHO* \\ CLAUDIO FAVA CHAGAS * \\ CIRO F'ERREIRA DA SILVA* \\ FRANCISCO PRADO REIS **
}

The scanning electron microscope (SEM) has been largely used, mainly in the past ten years, for studying the ependyma of many species (see Mitchell, 1980, for a review), providing important morphological bases for the elucidation of functional relationships between the ependyma and the cerebrospinal fluid (CSF).

Taking into account Fleischhauer's (1960) ideas, for whom, in the cat, the ependymal lining constitutes a mosaic of different areas related to distinct functional properties, we have been studying the ependyma of Bradypus tridactylus, from the histological and histochemical (Ferraz de Carvalho et al., 1975) as well as ultrastructural (Ferraz de Carvalho et al., 1976a) points of view. We have also performed morphofunctional studies on the interrelationships of the ependyma with the underlying nervous tissue and with the generically called supraependymal structures (Ferraz de Carvalho et al., 1976b and 1977).

The present study is a SEM analysis of the ependymal surface and some supraependymal structures, made in the whole brain ventricular system (BVS) of B. tridactylus.

\section{MATERIAL AND METHODS}

Two specimens of Bradypus tridactylus had their brains removed under Nembutal anesthesia, cut in slices $5 \mathrm{~mm}$ thick along frontal planes and fixed in Karnovsky's solution (1965) for about 48 hours.

The slices were then reduced to 24 fragments for each animal, in order to provide specimens of suitable size for scanning electron microscopy. These specimens were

* Dept. of Anatomy, Biomedical Sciences Institute, São Paulo University, Brazil; ** Dept. of Morphology, Sergipe Federal University, Brazil.

Acknowledgements - The authors wish to express their gratitude to the following: Prod. José Maria Soares Barata, Mr. Carlos Alberto Leite and Mr. Carlos Pereira Baltar, from the Department of Epidemiology, University of São Paulo Public Health Schoul; and Prof. Antonio Sesso, from the Department of Pathology, são Paulo Medical School. 
dehydrated in ethanol, $\mathrm{CO}_{2}$ critical point dried, and mounted on metal stubs with conductive material. Coating was carried out a carbon-gold vacuum evaporator *.

After observation at the SEM, selected fragments of the lateral ventricle were treated with propylene oxide, embedded in araldite and sectioned perpendicularly to

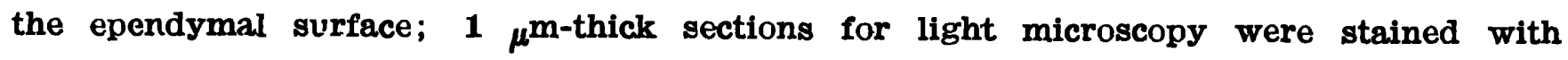
tolujdine blue - Azur II (1:1), being the thin sections for transmission electron microscopy (TEM) stained with lead citrate and uranyl acetate. All sections were made with an LKB Ultrotome**.

The SEM used was a JEOL JSM-P15 *, from the Department of Epidemiology of the São Paulo University Public Health School. The TEM was a Zeiss M-9A, from the Department of Pathology of the São Paulo Medical School.

\section{RESULTS}

The surface of the ependymal lining of $B$. tridactylus does not differ essentially from that of other animals and of man himself. While the presence of cilia and microvilli is a constant feature, the overall aspect is quite variable from one region to another.

Regions in which cilia are most numerous include the anterior horn (Fig. 1), interventricular foramen and cerebral aqueduct; these structures appear in moderate amounts in the foremost part of the anterior horn (Fig. 2), middle part of the lateral ventricle (including the lateral transition zone between floor and roof) and in the thir.l ventricle, being scarce in the posterior horn, medial wall of the lateral ventricle (Fig. 3) and in the floor and roof of the fourth ventricle, away from the opening of the cerebral aqueduct.

The cilium-rich areas usually present more irregular, elsewhere smoother cell surfaces. In such areas, the cilia seem to be evenly spread along the ependymal suriuce; in less densely-packed areas, one can observe that the tufts of cilia are displaced towards the boundaries of the polygonal cell surface, but can appear closer to the center in those regions with few cilia (Fig. 3); cells devoid of cilia occasionally occur in such areas. It is questionable whether they also appear in other regions, their cbservation becoming impaired by overlying cilia from neighboring cells (Fig. 1).

Microvilli are found mainly along the cell outlines, although some may also be observed scattered on the entire cell surface (Fig. 3). This is obviously more apparent in regions with moderate to few cilia. The microvilli vary in length, amount and packing in an apparently direct proportion to the abundance of cilia (Figs. 2 and 3).

Also found were a very small number of blebs, on cells of the anterior horn (Fig. 4) and cerebral aqueduct, and many supraependymal nerve-like fibers with bulb swellings (Figs. 3 and 4). These fibers, with variable diameter, appeared in all regions of the ventricular system, following no peculiar direction and branching at times. In 

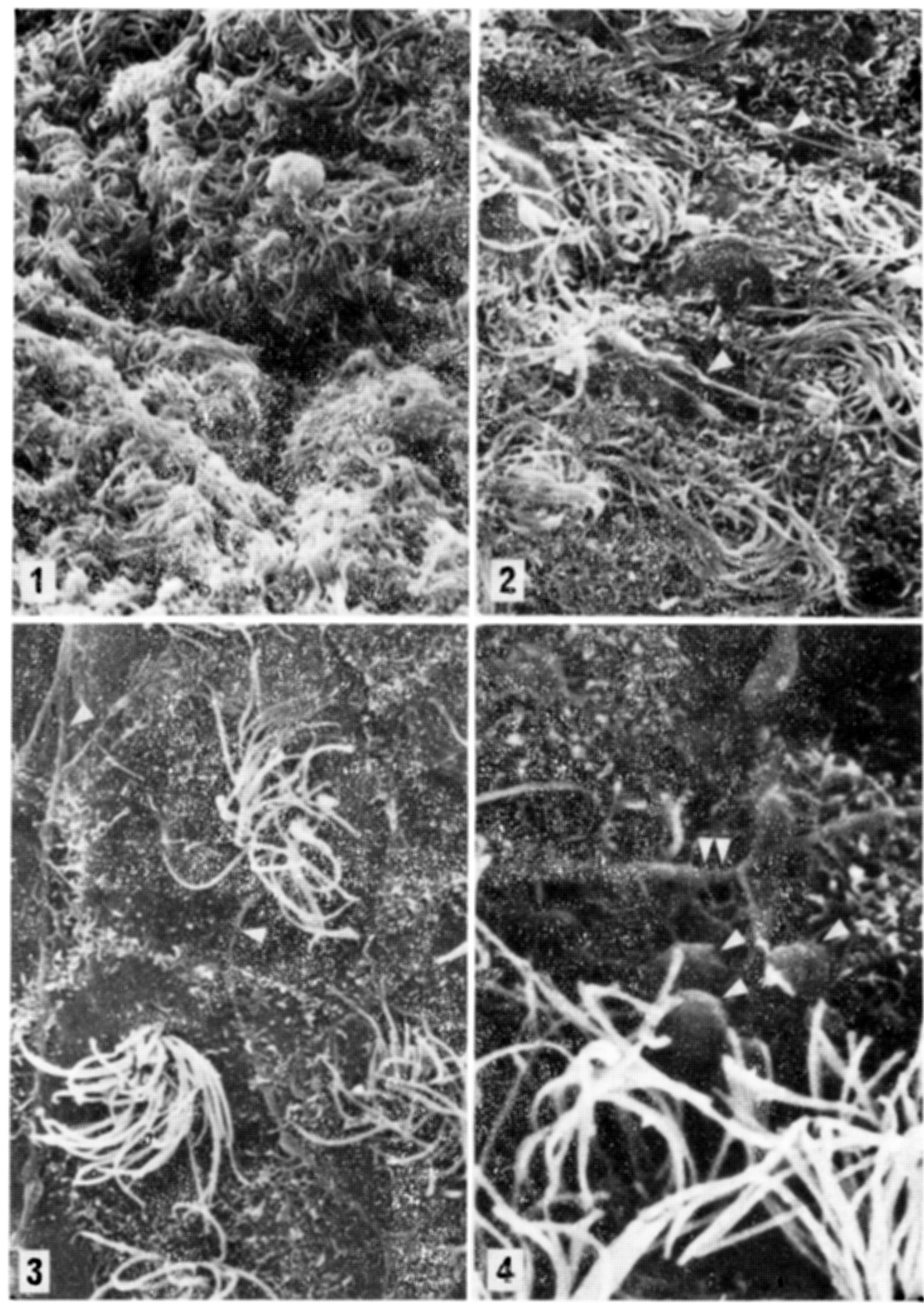

Fig. 1 - Anterior horn. Note the abundance of cilia. SEM, x2,850.

Eig. 2 - Anterior horn. Some supraependymal nerve-like fibers with bulb swellings can seen (arrowheads). $x 2,850$.

Fig. 3 - Medial wall of lateral ventricle, middle part. Note cilium tufts near center of cell surface, microvilli along cell outlines and also scattered on the cell surface. See Figs. 1 and 2 for comparison. Arronheads: supraependymal fibers with bulb dilations. $x 2,850$.

Fig. 4 - Anterior horn. Note blebs (arrowheads), branching supraependymal fiber (double arrowhead). $x 5.000$. 

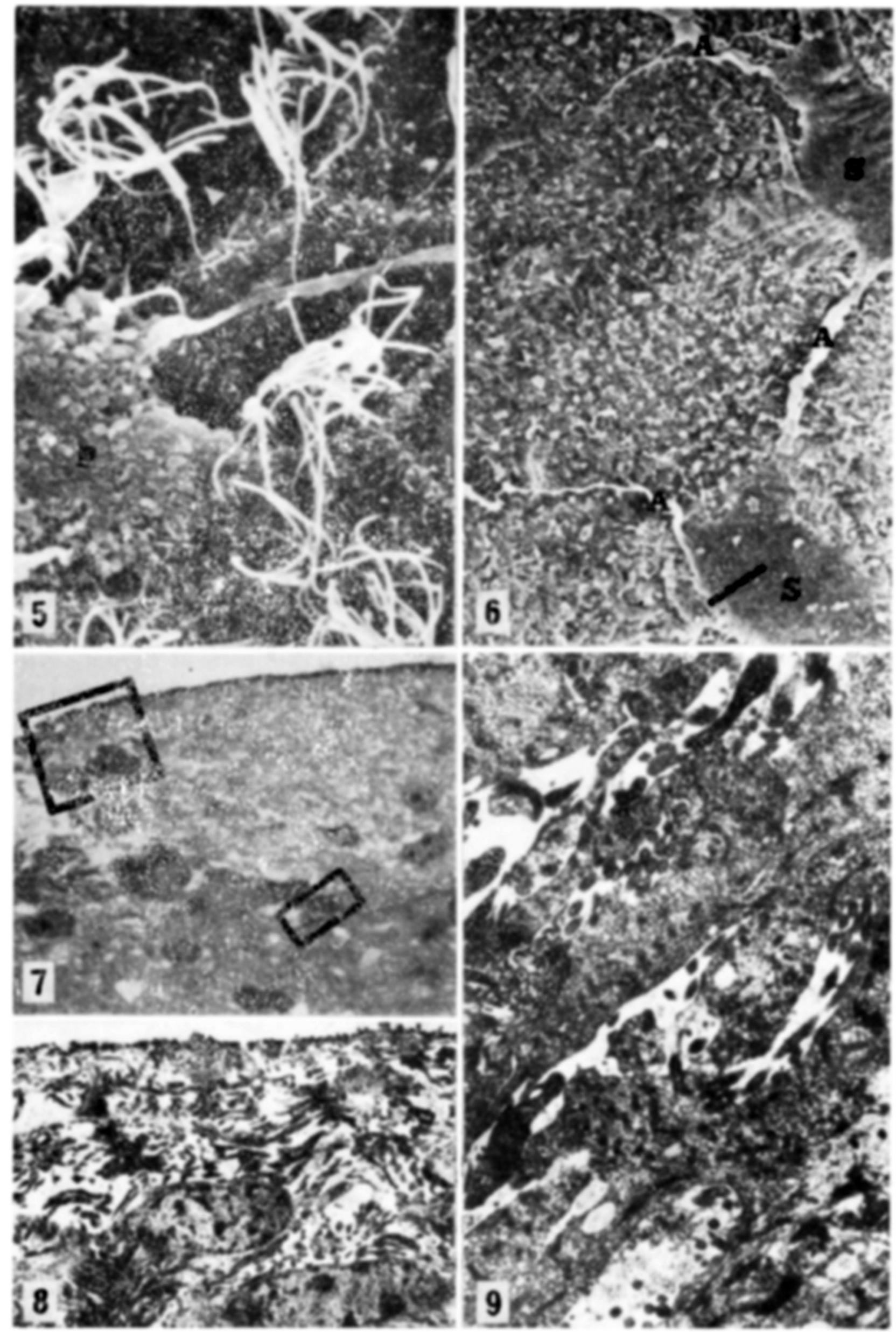

Fig. 5 - Medial wall of lateral ventricle. P: ependymal cell with protrusions; arrowheads: supraependymal fibers. $x 2,700$.

Fig. 6 - Lateral transition zone between the floor and roof of the lateral ventricle, anterior part. S: stellate formation; A: interconnecting arm; bar indicates site of section shown in Fig. 7. $x 190$.

Fig. 7 - Photomicrograph of $1 \mu$-thick araldite section of a stellate bulging. Large frame: area of Fig. 8. Small frame: area of Fig. 9; upper corner corresponds to upper lefthand corner of Fig. 9. x1,125.

Fig. 8 - Electronmicrograph of area shown in Fig. 7. Note fibrous meshwork, deeply-situated cell bodies. 208,800 .

Fig. 9 - Electronmicrograph of area shown in Fig. \%. Complex labyrinthic spaces can be seen to contain numerous cilia. $x 9,800$. 
some areas, we were able to observe fine fibers originating from bulb swellings and running towards cell limits, where these fibers seemed to plunge. The presence of fine unmyelinated fibers in ependymal intercellular spaces of $B$. tridactylus had already been observed at the TEM by Ferraz de Carvalho and col. (1976b).

A small number of ependymal cells with numerous small protrusions was found in the medial wall of the lateral ventricle (Fig. 5) and in the posterior horn.

In the transition zone between the lateral part of the floor and roof of the lateral ventricle of one animal, a group of stellate formations measuring an average $90 \times 190$ $\mu^{\mathrm{m}}$, interconnected by means of thin arms, was clearly observed (Fig. 6); these formations, with surfaces of fibrous aspect, were laterally separated from the underlying tissue by the presence of irregular spaces. Light microscopy of adjacent regions showed a flat-cell monolayered ependymal lining, their nuclei being situated near the surface. Ependymal-like cells seem to form an irregular monolayer between the bulgings and the underlying neuropil (Fig. 7); such bulgings are characterized by a prevailing fibrous structure and the absence of cell bodies close to the surface. TEM findings confirmed the presence of a fibrous meshwork consisting essentially of fibrous astrocyte processes (Fig. 8) showing actual, rather complex labyrinthic spaces particularly evident under the formation. In some of these spaces, limited by those ependymal-like cells, cilia could be found (Fig. 9). These deeply-situated glial cells, among which \&zonulae» or «fasciae adhaerentes» can be seen, retain some ependymal-cen features, though being more polymorphic. Some of these cells give off slender processes very similar to those of fibrous astrocytes (Fig. 8).

\section{COMMENTS}

The cilia of the brain ventricular system (BVS) surface of $B$. tridactylus are more extensively observed at the SEM than at the TEM (Ferraz de Carvalho et al., 1976a). Our findings on cilium-rich areas are consistent with those of Vonwiller \& Wigodskaya (1934), for whom narrower regions of the BVS would exhibit a greater number of cilia. These, for Kozlowski and col. (1973), would be of great importance for the circulation of biologically active substances towards certain regions, e.g. the hypothalamus and the hypophysis.

Our findings are similar to those of the many authors that described the cilia present in distinct areas of the BVS lining of different species (see Ferraz de Carvalho et al., 1976a, for a review), and particularly to those of Bruni and col. (1972); Clementi \& Marini (1972), Noack and col. (1972), Ribas (1977), Allen and col. (1978), Hetzel (1978a, b), Richards and col. (1978), and Weindl \& Schinko (1978), who studied these structures with the SEM.

Microvilli were observed in all examined areas of the BVS surface, confirming previous findings of ours (Ferraz de Carvalho et al., 1976a); they are, however, more evident at the SEM than at the TEM.

Usually considered absorptive structure of the ependyma, as in other cells where they occur, the microvilli have also been linked to the production of an 
ultrafiltrate of blood substances to the CSF (Pontenagel, 1962) as well as to secretion, as described for certain ependymal areas, e.g. the median eminence (Matsui \& Kobayashi, 1968; Schechter \& Weiner, 1972).

Rarely observed were the cilium-free ependymal cells described by some authors (Allen and col., 1978 in man, dog, hamster, mouse, rabbit, rat and gerbil; Hetzel, 1978, in the rabbit). On the other hand, ependymal protrusions like those described by Hetzel $(1978 a, b)$ were found, also is small number.

Bleb-like cell protrusions were seldom observed in B. tridactylus, either at the SEM or at the TEM (Ferraz de Carvalho et al., 1976a). These structures, reported to occur mainly in the third ventricle by many authors studying different species (Pontenagel, 1962; Takeichi, 1967; Nakai, 1971; Marquet and col., 1972; Schechter \& Weiner, 1972; Kozlowski, 1973; Hetzel, 1977/8; Weindl \& Schinko, 1978), have been linked to micro-apocrine secretion processes.

It is remarkable that, apart from the cilia, microvilli and nerve-like fibers, no other structure is as conspicuous in this animal as in other species.

We frequently found cells with microvilli located mainly on the cell periphery, which coud possibly be related to a higher absorption degree of the ependymal intercellular spaces (Brightman, 1968). In SEM, more than in TEM (Ferraz de Carvalho et al., 1976a), the aspect of the ependyma of $B$. tridactylus provides support to the participation of this lining in absorption processes; it does not, however, reveal a more expressive picture concerning secretion, as we had already pointed out (Ferraz de Carvalho et al., 1976a).

Among the so-called supraependymal structures, most frequently found were the fiber-like ones, with or without bulb dilations, forming plexuses of variable dimensions. Controversial as for their role, they have frequently been described, for a long time (Renaut, 1982) as structures of nervous nature. A great number of papers have been written on this subject, in the fields of light microscopy and TEM (see Ferraz de Carvalho et al., 1976a, for a review). Among more recent descriptions, to which ours are most similar, are the ones by Hetzel, 1977 and 1978; Noack and col., 1977; Weindl \& Schinko, 1978; Richards and col., 1980).

Though many of those structures are said to be of nervous nature, diverging opinions arise concerning their function: according to Agdhur (1922), Pesonen (1940), and Leonard (1968), for instance, these structures play a receptor role, while for Dierickx (1962) they act as osmoceptors; still others (Bargmann \& Scharer, 1951; Pensa, 1962; Ito, 1965; Rodrigues, 1967) admit the participation of such structures in CSF secretion processes.

We have not found, in the literature, any reference to the glio-ependymal interconnected stellate bulgings observed in the lateral ventricle of $B$. tridactylus. We stress, however, the fact that a very great number of authors describe the presence of fibrous structures of ependymal nature on the ventricular surface. Although few can be put forth about their functional role, it seems clear that, 
in our particular case, such structures would constitute a special kind of continuity solution of the ependymal surface; through them, the ventricular cavity would be able to communicate directly with the subependymal neuropil by means of labyrinthic spaces, part of which formed by irregularly shaped, cilium-bearing ependymal-like cells.

\section{SUMMARY}

Topographical variations of the ependymal surface of the whole brain ventricular system of Bradypus tridactylus were studied at the scanning electron microscope after $\mathrm{CO}_{2}$ critical point drying and carbon-gold coating. Certain selected areas were also studied at the transmission electron microscope, following standard technical procedures. We observed distinct patterns in the distribution of cilia, microvilli and supraependymal structures (nerve-like and fibrous astrocyte fibers), and also a small number of blebs. It the lateral transition zone between the floor and roof of the lateral ventricle were found interconrected stellate bulgings measuring an average $98 \times 190 \mu \mathrm{m}$, constituted by a complex meshwork of processes from fibrous astrocytes, without ependymal lining and with few cell bodies. In the junction between these formations and the underlying neuropil, ciliated ependymal-cell-kike glial cells were found to delimit complex labyrinthic spaces. Based on the morphological findings, morphofunctional considerations are made.

\section{RESUMO}

Estudo correlativo à microscopia eletrônica de varredura e de transmissão da superficie ependimal de Bradypus tridactylus.

Diferenças topográficas da superfície ependimal dos ventrículos encefálicos de Bradypus tridactylus foram estudadas à microscopia eletrônica de varredura (com processamento por ponto crítico de $\mathrm{CO}_{2}$ e recobrimento com carbono e ouro). Certas regiões selecionadas foram também analisadas à microscopia eletrônica de transmissão, segundo métodos convencionais. Foram observados distintos padrões de distribuição de cílios, microvilos e estruturas supra-ependimais, por toda a superfície ventricular, e também saliências vesiculares em pequeno número. Lateralmente, entre o teto e o soalho do ventrículo lateral, são descritas elevações estreladas interconectadas, medindo em média $98 \times 190 \mu \mathrm{m}$, desprovidas de revestimento ependimal e constituídas por um complexo emaranhado de processos de astrocitos fibrosos e poucos corpos celulares. Na junção entre essas formações e o tecido nervoso subjacente foram encontradas células gliais semelhantes às células ependimais, dotadas inclusive de cílios, delimitando complexos espaços labirínticos. São feitas considerações morfo-funcionais concernentes aos achados morfológicos. 


\section{REFERENCES}

1. AGDUHR, E. - Ueber ein zentrales Sinneorgan (?) bei den Vertebraten. Z.Anat. Entwicks-Gesch. 66:223, 1922.

2. ALLEN, D. J.; PERSKY, B. \& LOW, F. N. - Some regional variations in ventricular lining material in laboratory animals and man. Scanning electron Microsc. 2:45, 1978.

3. BARGMANN, W. \& SCHARRER, E. - The site of origin of the hormones of the posterior pituitary. Amer. Scientist 39:245, 1951.

4. BRIGHTMANN, M. W. - The intracerebral movement of proteins injected into blood and cerebrospinal fluid of mice. Prog.Brain Res. 29:19, 1968.

5. BRUNI, J. E.; MONTEMURO, D. G.; GLATTENBURG, R. E. \& SINGH, R. P. The scanning electron microscopic study of the ependymal surface of the third ventricle of the rabbit, rat, mouse and human brain. Anat. Rec. 174:407, 1972.

6. CLEMENTI, F. \& MARINI, D. - The surface fine structure of the walls of cerebral ventricles and choroid plexus in cat. Z.Zellforsch. 123:82, 1972.

7. DIERICKX, K. - The dentrites of the preoptic neurosecretory nucleus of Rana temporaria and the osmoreceptors. Arch.int.Pharmacodyn. 140:708, 1962.

8. FERRAZ DE CARVALHO, C. A. \& COSTACURTA, L. - Ultrastructural study on topographical variations of the ependyma in Bradypus tridactylus. Acta. anat. (Basel) 94:369, (1976(A).

9. FERRAZ DE CARVALHO, C. A.; KÖNIG JR., B. \& RODRIGUES JR., A. J. Uitrastructural study on the relations among nerve elements and ependymal cells of the Bradypus tridactylus. Rev.bras.Pesq.méd.biol. 9:137, 1976(B).

10. FERRAZ DE CARVALHO, C. A.; KóNIG JR., B. \& SOUZA, R. R. de - Ultras-tr.ctural study of the subependymal tissue in the Bradypus tridactylus. Rev.bras. Pusq.méd.biol. 10:109, 1977.

11. FerRaz DE CaRVAlHo, C. A.; COSTACURTa, L. \& CaRValHo Filho, J. R. - Histological and histochemical study on the ependyma of Bradypus tridactylus. Acta. anat. (Basel) 92:424, 1975.

12. FLEISCHHAUER, $K$. - Regional differences in the structure of the ependymal layers of the cerebral ventricles of the cat. In KETY, S. S. \& ELKES, J. E. - The Regional Chemistry Physiology and Pharmacology of the Nervous System. Bethesda, National Inst. of Mental Health, 1961. p. 279-283.

13. HETZEL, W. - A scanning electron microscopic study of the cornu anterius and inferius of the lateral ventricle of the monikey's brain. Sccanning electron Microsc. 2:587, 1977.

14. HETZEL, W. - Ependymal structure of the anterior and inferior horn of the lateral ventricle of the rabbit brain. Scanning electr.Microsc. 2:129, 1978.

15. HETZEL, W. - The posterior horn and collateral trigone of the lateral ventricle of the monkey brain (Macaca speziosa): a scanning electron microscopic study. Cell Tiss.Res. 186:161, 1978.

16. ITO, H. - The receptor in the reptilian brain. J.Hirnforsch. 7:943, 1965.

17. KOZLOWSKY, G. P.; SCOTT, D. E. \& DUDLEY, G. K. - Scanning electron microscopy of the third ventricle of sheep. Z.Zellforsch. 136:169, 1973.

18. LEONHARDT, H. - Intraventrikuläre markhaltige Nervenfasern nahe der Apertura lateralis ventriculi quarti des Kanninchengehirns. Z.Zellforsch. 84:1, 1968.

19. MARQUET, E.; SOBEL, H. J.; SCHWARZ, E. \& WEISS, M. - Secretion by ependymal cells of the neurohypophysis and saccus vasculosus of Polyypterus ornatipinnis (Osteichthyes). J.Morph. 137:111, 1972.

20. MATSUI, T. \& KOBAYASHI, H. - Surface protrusions from the ependymal cells of the median eminence. Arch.Anat. (Strasbourg) 51:430, 1968.

21. MITCHELL, J. A. - Scanning electron microscopy of brain ventricular surfaces: a bibliography. Scanning electr.Microsc. 3:475, 1980.

22. NAKAI, $\mathbf{Y}$. - Fine structure and its functional properties of the ependymal cell in the frog median eminence. Z.Zellforsch. 122:15, 1971. 
23. NOACK, W.; DUMITRESCU, L. \& SCHWEICHEL, J. - Scanning and electron microscopical investigation of the surface structures of the lateral ventricles in the cat. Brain Res. 46:121, 1972.

24. PENSA, A. - Della esistenza di fibre nervose aventi speciali rapporti col ependyma. Boll. Soc. med. chir. (Pavia), 1903. Apud AGDUHR, E. 1922.

25. PESONEN, N. - Ueber die intraependymalen Nervenelemente. Anat.Anz. 90:193, 1940.

26. PONTENAGEL, M. - Elektronenmikroskopische Untersuchungen am Ependym der Plexus chorioidei bei Rana esculenta und Rana fusca (Roesel). Z.mik.-anat.Forsch. 68:371, 1962.

27. RENAUT - Recherches sur les centres amyeliniques: la neuroglie et l'ependyme. Arch.Physiol.norm.pathol 2:9, 1882. Apud PESONEN, N., 1940.

28. RIBAS, J. L. - The rat epithalam 's: correlative scanning-transmission electron microscopy of supraependymal nerves. Cell.Tiss.Res. 182:1, 1977.

29. RICHARDS, J. G.; LOREZ, H. P.; COLOMBO, V. E.; GUGGENHEIM, R. \& IEISS, D. - Supraependymal nerve fibers in human brain: correlative transmission and scanning electron microscopical and fluorescence histochemical studies. Neuroscience E: $: 1489,1980$.

30. RODRIGUES, E. M. - Neurosecretory system of the toad Bufo arenarum Hensel and its changes during inanition. Gen.comp.Endocr. 4:684, 1964.

31. SCHECHTER, J. \& WEINER, R. - Ultrastructural changes in the ependymal lining of the median eminence following the intraventricular administration of catecholamine. Anat.Rec. 172:643, 1972.

32. TAKEICHI, M. - The fine structure of ependymal cells. II An electron microscopic str:dy of the soft-shelled turtle paraventricular organ, with special reference to the tirst structure of ependymal cells and socalled albuminous substance. Z.Zellforsch. $76: 471,1967$.

33. VONWILLER, P. \& WIGODSKAYA, R. R. - Mikroskopische Beobachtung der Bewegung des Liquors im lebenden Gehirn. Z.Anat. Fntwickl.Gesch. 102:290, 1934.

34. WEINDL, A. \& SCHINKO, I. - The ventricular system of the opossum brain. Scanning electr.Microsc. 2:861, 1978.

Departamento de Anatomia, Bloco 30 - Instituto de Ciencias Biomédicas - Universidade de São Paulo - Caixa Postal 4365 - 01000 são Paulo - Brasil. 